\title{
PENGATURAN PERLINDUNGAN HUKUM SEBAGAI PEKERJA GOJEK BAGI PENYANDANG DISABILITAS TUNA RUNGU DALAM UNDANG-UNDANG NOMOR 13 TAHUN 2003
}

\author{
Oleh : \\ Dian Puspitawati* \\ I Nyoman Darmadha** \\ Program Kekhususan Hukum Bisnis, Fakultas Hukum, \\ Universitas Udayana
}

\begin{abstract}
ABSTRAK
Peluang pekerjaan bagi penyandang disabilitas atau "difable" (differently abled people) perlu diperhatikan sesuai dengan hukum positif di Indonesia yaitu perlindungan hukum terhadap hak pekerjaan bagi penyandang disabilitas yang diatur dalam Pasal 5, Pasal 6 dan Pasal 67 Undang-Undang Nomor 13 Tahun 2003 tentang Ketenagakerjaan. Sesuai dengan Pasal 67 ayat (1) UndangUndang Nomor 13 Tahun 2003 tentang Ketenagakerjaan tersebut Perusahaan GOJEK memberikan kesempatan bagi penyandang disabilitas tuna rungu untuk bermitra dengan perusahaan GOJEK karena perusahaan GOJEK berkomitmen membuka kesempatan yang sama dan menjunjung tinggi kesetaraan dalam hak kerja kepada penyandang disabilitas. Penelitian ini bertujuan untuk mengkaji dan memahami pengaturan perlindungan hukum sebagai pekerja GOJEK bagi penyandang disabilitas tuna rungu dalam Undang-Undang Nomor 13 Tahun 2003. Penulisan jurnal hukum ini menggunakan jenis penelitian hukum normatif melalui pengkajian kepustakaan dengan jenis pendekatan perundangundangan serta menggunakan berbagai data sekunder seperti buku-buku dan jurnal-jurnal hukum. Kesimpulan pokok dari jurnal ini adalah regulasi terkait hak memperoleh pekerjaan bagi penyandang disabilitas tuna rungu sudah cukup memadai yang ditandai dengan berbagai peraturan perundang-undangan yang berlaku mulai Pasal 27 ayat (2) dan 28D ayat (2) UUD NRI Tahun 1945, Pasal 5, Pasal 6 dan Pasal 67 UU Nomor 13 Tahun 2003 tentang Ketenagakerjaan, Pasal 11 UU Nomor 8 Tahun 2016 tentang Penyandang Disabilitas serta Pasal 38 ayat (1) UU Nomor 39 Tahun 1999 tentang Hak Asasi Manusia.
\end{abstract}

*Penulis pertama Dian Puspitawati adalah Mahasiswi Fakultas Hukum Universitas Udayana, email: puspitadian98@gmail.com

${ }^{* *}$ Penulis kedua I Nyoman Darmadha adalah Dosen Fakultas Hukum Universitas Udayana, email: nyoman_darmadha@unud.ac.id 


\title{
Kata Kunci : penyandang disabilitas, hukum ketenagakerjaan, perlindungan hukum
}

\begin{abstract}
Job opportunities for disabilities or "difable" (differently abled people) rarely get attention based on positive law in Indonesia, especially legal protection against right to work for disabilities that regulated in Article 5, Article 6 and Article 67 State Number 13 Year 2003 about Labor. Based on Article 67 paragraph (1) State Number 13 Year 2003 about Labor, GOJEK company provide an opportunity for a deaf of disabilites to be a partner with GOJEK company because GOJEK company is committed to open the same opportunity and upholding equality in the right of work for disabilities. This study aims to examine and understand legal protection as a GOJEK workers for a deaf of disabilites in Statute Number 13 Year 2003. This paper uses the normative legal research, namely statute approach by reviewing positive statutes and regulations using various secondary data such as law books and legal journals. The main conclusion of this journal is regulations related of right to work already sufficient for a deaf of disabilities which marked by various laws and regulations that applies start from Article 27 (2) and 28D (2) Constitution Year 1945, Article 5, Article 6 and Article 67 Statute Number 13 Year 2003 about Labor, Article 11 Statute Number 8 Year 2016 about People with Disabilities and Article 38 paragraph (1) Statute Number 39 Year 1999 about Human Right.
\end{abstract}

\section{Keywords: difable, labor law, legal protection}

\section{PENDAHULUAN}

\subsection{Latar Belakang}

Keberadaan penyandang disabilitas yang masih tersisihkan dari masyarakat umum menjadi salah satu kendala bagi kaum penyandang disabilitas, terutama kendala dalam memperoleh hak bekerjanya. ${ }^{1}$ Penyandang disabilitas tentu tidak terlepas dari kendala pekerjaan karena memiliki kekurangan dalam fisiknya, yaitu pekerja disabilitas akibat ketidaksempurnaannya sering

${ }^{1}$ Maria Nurma Septi Arum Kusumastuti, 2016, "Perlindungan Hukum dari Diskriminasi bagi Penyandang Disabilitas dalam Dunia Kerja”, Jurnal Hukum Program Kekhususan Hukum Ekonomi dan Bisnis Fakultas Hukum Universitas Atma Jaya (UAJY), Yogyakarta, h. 1. 
mendapatkan perlakuan diskriminasi untuk memperoleh hak pekerjaan. $^{2}$

Hak-hak penyandang disabilitas merupakan perwujudan dari keikutsertaan pemerintah dalam mewujudkan ketenagakerjaan yang setara sebagai pelaksanaan perlindungan bagi warga negara yaitu tenaga kerja ${ }^{3}$ yang berstatus sebagai penyandang disabilitas. Hal ini dapat dilihat dari salah satu hal yang menjadi syarat mutlak dimiliki yaitu sehat jasmani maupun rohani, baik dari segi fisik maupun mental ${ }^{4}$ padahal penyandang disabilitas memiliki hak dan potensi untuk berkontribusi sebagai tenaga kerja dalam pembangunan.

Jika diperhatikan lebih lanjut mengenai perlindungan hukum terhadap peluang kerja bagi penyandang disabilitas sangat penting di dalam melakukan penelitian hukum ini. Dalam Pasal 5 UU Nomor 13 Tahun 2003 menyatakan bahwa setiap tenaga kerja memiliki kesempatan yang sama tanpa diskriminasi untuk memperoleh pekerjaan. Jadi, perlu diperhatikan mengenai pekerjaan bagi penyandang disabilitas terhadap kesetaraan hak peluang kerja bagi penyandang disabilitas dengan melihat kemampuan tenaga kerja penyandang disabilitas yang bersangkutan karena perlu kita ketahui bahwa penyandang disabilitas secara lebih terperinci memiliki jenis dan kriteria disabilitas ${ }^{5}$ sehingga dari derajat

2Yuni Ratnasari dan Made Suksma Prijandhini Devi Salain, 2016, "Perlindungan Hukum bagi Pekerja Disabilitas terhadap Hak Memperoleh Pekerjaan”, Jurnal Hukum Bisnis Fakultas Hukum Universitas Udayana, Vol. 04 No. 03, April 2016, h. 2.

3I Made Udiana, 2016, Kedudukan dan Kewenangan Pengadilan Hubungan Industrial, Udayana University Press, Denpasar, h. 3.

4Jazim Hamidi, 2016, "Perlindungan Hukum terhadap Disabilitas dalam Memenuhi Hak Mendapatkan Pendidikan dan Pekerjaan", Jurnal Hukum Ius Quia Iustum Faculty of Law Universitas Islam Indonesia, Volume 23 Nomor 4, Oktober 2016, h. 654.

${ }^{5}$ Sulistyo Saputro et. al., 2015, Analisis Kebijakan Pemberdayaan dan Perlindungan Sosial Penyandang Disabilitas, Deputi Bidang Koordinasi Penanggulangan Kemiskinan dan Perlindungan Sosial, Surakarta, h. 38. 
penyandang disabilitas yang berbeda membutuhkan perlakuan khusus yang berbeda juga.

Penamaan gangguan disabilitas berdasarkan tipe dan jenis disabilitas mengacu pada kondisi ketergangguan dari penyandang disabilitas itu sendiri sehingga perlu diperhatikan mengenai kesetaraan dalam hak pekerjaan bagi penyandang disabilitas dengan melihat kemampuan dari tenaga kerja yang bersangkutan. Tipe dan jenis penyandang disabilitas yang dimaksud tersebut dapat diklasifikasikan menjadi 3 yaitu $^{6}$ : (1) tipe A, B, C, D dan E1 meliputi tunanetra, tunarungu, tunawicara, tunadaksa dan tunalaras yang dikelompokkan ke dalam jenis disabilitas fisik, (2) tipe E2 dan $F$ meliputi tunalaras dan tunagrahita yang dikelompokkan ke dalam jenis disabilitas mental, (3) tipe G meliputi tuna ganda.

Tuna rungu merupakan gangguan pada organ pendengaran sehingga mengakibatkan ketidakmampuan mendengar mulai dari tingkat ringan sampai tingkat berat yang diklasifikasikan menjadi tuli (deaf) dan kurang dengar (hard of hearing). ${ }^{7}$ Penyandang tuna rungu merupakan individu yang memiliki hambatan dalam pendengaran baik permanen maupun tidak permanen. ${ }^{8}$ Karena memiliki hambatan dalam pendengaran, penyandang disabilitas tuna rungu memiliki hambatan dalam berbicara sehingga bisa juga tuna rungu ini merupakan tuna wicara. Cara berkomunikasi dengan penyandang disabilitas tuna rungu melibatkan bahasa verbal, bahasa isyarat, dan bahasa tubuh sehingga penyandang disabilitas tuna rungu cenderung kesulitan dalam memahami konsep dari sesuatu yang abstrak sehingga hal ini tentu saja akan

${ }^{6}$ Ibid., h. 6.

7Tati Hernawati, 2007, "Pengembangan Kemampuan Berbahasa dan Berbicara Tuna Rungu", Jurnal Jurusan PLB FIP Universitas Pendidikan Indonesia, Volume 7 Nomor 1, Juni 2007, h. 2.

8Sulistyo Saputro et. al., op. cit., h. 7. 
berpengaruh terhadap penyandang disabilitas tuna rungu untuk melakukan kegiatan atau aktivitas, salah satunya yaitu dalam hal melaksanakan suatu pekerjaan.

\subsection{Rumusan Masalah}

Permalasahan yang diidentifikasi dalam kajian penulisan jurnal ini yaitu :

1. Bagaimana pengaturan perlindungan hukum sebagai pekerja perusahaan GOJEK penyandang disabilitas tuna rungu dalam Undang-Undang Nomor 13 Tahun 2003?

2. Bagaimana upaya pemerintah dan konsumen GOJEK di dalam melaksanakan perlindungan terhadap pekerja GOJEK penyandang disabilitas tuna rungu?

\subsection{Tujuan Penulisan}

Penelitian ini bertujuan untuk mengkaji pengaturan perlindungan hukum serta upaya pemerintah dan konsumen GOJEK di dalam melaksanakan perlindungan hukum terhadap pekerja GOJEK penyandang disabilitas tuna rungu dalam UndangUndang Nomor 13 Tahun 2003.

\section{ISI MAKALAH}

\subsection{Metode Penelitian}

Penulisan jurnal hukum ini menggunakan jenis penelitian hukum normatif melalui pengkajian kepustakaan dengan objek kajian berupa peraturan perundang-undangan tertulis serta bukubuku dan jurnal-jurnal hukum. ${ }^{9}$ Bersifat normatif maksudnya adalah penelitian hukum yang bertujuan untuk memperoleh 
pengetahuan normatif tentang hubungan antara satu peraturan dengan peraturan lain. ${ }^{10}$ Pendekatan yang digunakan menganalisis bahan-bahan hukum yang dilakukan dengan cara deskriptif, analisis serta argumentatif ${ }^{11}$ serta menganalisis pasal-pasal mengenai permasalahan yang dikaji yaitu pengaturan perlindungan hukum sebagai pekerja perusahaan GOJEK bagi penyandang disabilitas tuna rungu dalam Undang-Undang Nomor 13 Tahun 2003.

\subsection{Pembahasan}

2.2.1 Pengaturan Perlindungan Hukum Pekerja Perusahaan GOJEK Penyandang Disabilitas Tuna Rungu dalam Undang-Undang Nomor 13 Tahun 2003

Penyandang difable merupakan orang yang mengalami keterbatasan dalam hal kemampuan fisik, mental, sensorik maupun intelektual yang mengganggu di dalam menjalankan kegiatan atau aktivitas, baik sejak lahir ataupun setelahnya, karena kecelakaan dan lain hal. Sebagai suatu hambatan untuk melakukan kegiatan bagi aktivitas yang efektif terhadap kesetaraan dalam keterlibatan terhadap kehidupan sosial, maka dalam kondisi tersebut untuk menciptakan partisipasi penuh dan efektif dalam kehidupan bermasyarakat berdasarkan kesamaan hak ${ }^{12}$ penyandang difable memerlukan suatu fasilitas khusus agar mudah di dalam menjalankan kegiatan atau aktivitas pribadi maupun sosial.

Meningkatkan kesejahteraan seluruh rakyat Indonesia tentu merupakan tujuan utama dari pembangunan nasional bangsa

${ }^{10}$ Ediwarman, 2015, Monograf Metodologi Penelitian Hukum: Panduan Penulisan Skripsi, Tesis dan Disertasi, PT. Sofmedia, Medan, h. 97.

${ }^{11}$ Peter Mahmud Marzuki, 2016, Penelitian Hukum Edisi Revisi, Prenadamedia Group, Jakarta, h. 133.

${ }^{12}$ Sulistyo Saputro et. al., 2015, op. cit., h. 5. 
Indonesia. Penyandang difable itu sendiri merupakan salah satu dari golongan rentan sehingga perlu adanya suatu penanganan kerentanan yang terintegrasi dan terencana.

Berdasarkan hal tersebut maka salah satu penanganannya yaitu berupa suatu perlindungan hukum di dalam kondisi faktual dari dinamika perkembangan ketenagakerjaan bagi penyandang difable sehingga kemampuan dari penyandang difable dapat digunakan sebagai suatu persiapan hidup yang lebih baik dan mandiri, baik dari segi ekonomi maupun sosial.

Kesetaraan terhadap jenis dan kriteria peluang kerja bagi penyandang disabilitas di Indonesia harus dipandang setara dan sejajar terhadap seluruh warga negara Indonesia dalam hak mendapatkan pekerjaan. ${ }^{13}$ Kesetaraan baik dari segi akses maupun layanan bagi penyandang difable juga sepenuhnya perlu diperhatikan karena kedua hal tersebut merupakan kebutuhan dasar bagi penyandang difable pada posisi yang setara dan seimbang di dalam pemenuhan hak khususnya dalam pemenuhan hak pekerjaan bagi penyandang difable.

Kemampuan penyandang disabilitas di dalam dunia kerja tentunya perlu diperhatikan agar terciptanya suatu kesetaraan dalam hal peluang kerja secara adil, sebab keadaan disabilitas merupakan kehendak dari Tuhan sehingga baik dari lingkungan masyarakat maupun Pemerintah harus turut serta dalam hal melindungi kesetaraan peluang kerja bagi penyandang disabilitas.

Jika melihat formulasi Pasal 1 ayat (1) UU Nomor 8 Tahun 2016 tentang Penyandang Disabilitas maka penyandang disabilitas dilindungi oleh kesamaan hak. Kemudian, di dalam Pasal 27 ayat

${ }^{13}$ Alvina Kristanti, 2013, "Perlindungan Hukum terhadap Tenaga Kerja Penyandang Cacat atas Hak Mendapatkan Pekerjaan Dikaitkan dengan Peraturan Perundang-undangan Ketenagakerjaan", Tesis Fakultas Hukum Universitas Kristen Maranatha, Jawa Barat, h. vi. 
(2) dan Pasal 28D ayat (2) UUD Negara RI Tahun 1945 dapat disimpulkan bahwa intinya setiap orang, termasuk penyandang disabilitas itu sendiri mempunyai hak kesetaraan di dalam hal pekerjaan serta dari segi kemanusiaan yaitu penghidupan yang sesuai atau layak bagi penyandang disabilitas itu sendiri. ${ }^{14}$

Perlindungan hukum terhadap peluang kerja bagi penyandang disabilitas di Indonesia dapat dilihat lebih mendalam di dalam Pasal 5, Pasal 6 dan Pasal 67 UU Nomor 13 Tahun 2003 tentang Ketenagakerjaan yang berintikan kesetaraan terhadap hak memperoleh pekerjaan di dalam pelaksanaannya tanpa diskriminasi dari pihak manapun serta dalam ruang lingkup pengusaha dari perusahaan yang ada di Indonesia wajib memberikan suatu perlindungan bagi penyandang disabilitas sesuai jenis dan kriteria penyandang disabilitas itu sendiri.

Berdasarkan Pasal 67 ayat (1) UU Nomor 13 Tahun 2003 tentang Ketenagakerjaan menyatakan bahwa pengusaha yang mempekerjakan tenaga kerja penyandang cacat wajib memberikan perlindungan sesuai dengan jenis dan derajat kecacatannya. Penjelasan dari pasal ini yaitu perlindungan sebagaimana dimaksud dalam Pasal 67 ayat (1) UU Nomor 13 Tahun 2003 tentang Ketenagakerjaan ini misalnya penyediaan aksesibilitas, pemberian alat kerja, dan alat pelindung diri yang disesuaikan dengan jenis dan kecatatannya. Jadi, berdasarkan Pasal 67 ayat (1) UU Nomor 13 Tahun 2003 dapat mewujudkan atau terlaksananya Undang-Undang Nomor 13 Tahun 2003 tentang Ketenagakerjaan terhadap perlindungan bagi penyandang difable sesuai dengan tipe, jenis dan kriteria penyandang disabilitas khususnya penyandang disabilitas tuna rungu dan terwujudnya Undang-Undang

${ }^{14}$ Hardijan Rusli, 2011, Hukum Ketenagakerjaan Berdasarkan UU No. 13/2003 tentang Ketenagakerjaan dan Peraturan Terkait Lainnya Edisi Kedua, Ghalia Indonesia, Bogor, h. 7. 
Ketenagakerjaan yang menegakkan keadilan, kepastian serta kemanfaatan hukum bagi seluruh tenaga kerja di Indonesia.

Di dalam melaksanakan Pasal 67 ayat (1) Undang-Undang Nomor 13 Tahun 2003 ini, perusahaan GOJEK memberikan peluang kepada para mitra untuk mendapatkan kesempatan bekerja dengan beberapa lembaga sebagai penyalur mitra-mitra penyandang disabilitas. Para penyandang disabilitas tuna rungu merupakan kelompok penyandang disabilitas dengan jenis pekerjaan yang terbatas sehingga GOJEK memberikan peluang kerja kepada penyandang disabilitas tuna rungu untuk bekerja di bagian GO-LIFE dan GO-MASSAGE sehingga menghilangkan batasan atas keraguan akan kemampuan penyandang disabilitas dan memberikan peluang pekerjaan yang sama kepada mereka untuk terus mengembangkan kemampuan minat dan bakatnya dalam hal pekerjaan.

Kemudian, perlindungan hukum terhadap peluang kerja penyandang disabilitas juga tertuang pada UU Nomor 8 Tahun 2016 tentang Penyandang Disabiltias. Salah satu konsideran undangundang ini berintikan bahwa Indonesia memperhatikan kesetaraan kedudukan difable demi terwujud serta terlaksananya kesamaan termasuk dalam hak pekerjaan yang dapat menjamin pelaksanaannya. Pasal 5 ayat (1) dan Pasal 11 undang-undang ini juga menekankan bahwa penyandang difable berhak mendapatkan kesetaraan dan keadilan yang meliputi perlindungan hukum dalam hal peluang kerja bagi penyandang disabilitas di Indonesia. Perlu diperhatikan lagi di dalam kedua pasal tersebut bahwa seorang difable berhak memiliki kedudukan yang setara dalam hal pekerjaan yang dilaksanakan oleh Pemerintah baik dari segi jenis dan kriteria pekerjaan, gaji/upah, tanggung jawab serta akomodasi dan perlakuan yang berkeadilan dalam hal karir. 
Kemudian, jika memperhatikan hukum positif lainnya yaitu Pasal 38 ayat (1) UU No. 39 Tahun 1999 tentang HAM ingin meyampaikan bahwa semua orang termasuk juga penyandang difable mempunyai kesempatan yang sama untuk mengembangkan dirinya.

Penyandang difable berhak memperoleh sikap, perlakuan serta perlindungan berkenaan dengan kekhususannya. Atas dasar kesetaraan maka kondisi penyandang difable dapat diindikasi bukanlah merupakan suatu keadaan yang menjadi suatu hambatan baik dari sikap maupun lingkungan untuk menjalankan berbagai kegiatan atau aktivitas layaknya orang normal lainnya.

Tidak seorangpun dapat membatasi seorang penyandang disabilitas untuk mendapatkan hak dalam hal pekerjaan dengan memperhatikan Hukum Postitif Indonesia yang berlaku serta mendapatkan perlindungan hukum terhadap peluang kerja sesuai dengan kemampuan, keahlian, jenis dan kriteria penyandang disabilitas itu sendiri di dalam proses pengembangan diri demi terwujudnya suatu keadilan dan kesetaraan hukum bagi penyandang difable dalam hak pekerjaan.

\subsubsection{Upaya Pemerintah dan Masyarakat Melaksanakan Perlindungan Hukum terhadap Tenaga Kerja Difable}

Berdasarkan Pasal 102 ayat (1) UU nomor 13 Tahun 2013 tentang Ketenagakerjaan, fungsi pemerintah dalam melaksanakan hubungan industrial adalah menetapkan kebijakan, memberikan pelayanan, melaksanakan pengawasan, melakukan penindakan terhadap pelanggaran peraturan perundang-undangan ketenagakerjaan sehingga pemerintah sebagai penyelenggara 
negara di bidang ketenagakerjaan harus dapat melaksanakan fungsi negara dengan baik. ${ }^{15}$

Peran dan fungsi pemerintah dalam hal ini berkaitan dengan perlindungan hukum di mana pemerintah wajib melindungi hak asasi warganya berdasarkan prinsip persamaan hak, demokrasi, keadilan sosial setara dan anti diskriminasi ${ }^{16}$ sehingga upaya pemerintah melaksanakan perlindungan hukum terhadap tenaga kerja difable sangatlah berkaitan dengan Pancasila yaitu sila kedua dan sila kelima dalam hal ini berarti bahwa manusia harus saling membantu dan melengkapi, oleh karena itu manusia wajib dan berhak untuk hidup sesuai kodrat manusia yang memerlukan masyarakat dan negara karena Pancasila sebagai falsafah bangsa dan negara Indonesia memiliki visi dasar yang bersumber pada hakikat manusia, yang memberikan isi dan arah dari seluruh kehidupan kemasyarakatan dan bersumber pada hakikat kodrat manusia sebagai pendukung negara.

Pengaplikasian di dalam terwujudnya hak ekonomi serta hak sosial di dalam mewujudkan keadilan HAM tentu berhak juga diperoleh oleh penyandang difable. ${ }^{17}$ Penyandang difable berhak memperoleh kesetaraan seperti manusia normal lainnya di dalam kehidupan di mana demi terselenggaranya hal tersebut perlu adanya apresiasi dan kepastian pemerintah demi terlaksananya perlindungan hukum terhadap tenaga kerja penyandang disabilitas yang tertuang dalam bentuk strategi m[gcc.

Pemberian kepercayaan terhadap pengembangan kegiatan maupun program serta dorongan berupa dana dukungan dari

15I Made Udiana, 2018, Industrialisasi dan Tanggung Jawab Pengusaha terhadap Tenaga Kerja Terlibat Hukum, Udayana University Press, Denpasar, h. 83.

16 Ibid., h. 85. Medan, h. 62.

${ }^{17}$ Agusmidah, 2010, Dinamika Hukum Ketenagakerjaan, USU Press, 
pemerintah terhadap Dewan Nasional Indonesia untuk Kesejahteraan Sosial dan Organisasi Penyandang Cacat tentunya akan sangat berpengaruh terhadap terlaksananya perlindungan dari segi hukum positif bagi tenaga kerja penyandang disabilitas. ${ }^{18}$ Perwujudan yang dapat dilakukan baik dari dilakukannya pelatihan terhadap penyandang disabilitas dan program pemberdayaan yang tepat agar penyandang disabilitas di sini menjadi tenaga yang profesional dan bermutu sehingga penyandang disabilitas ini mempunyai tenaga kerja yang diadaptasi dan disesuaikan dengan bahan-bahan pelatihan agar dapat memenuhi kebutuhan dari penyandang disabilitas sesuai pekerjaan dengan kualifikasi yang diisyaratkan yang diwujudkan dalam bentuk sertifikat bagi tenaga kerja penyandang disabilitas tuna rungu. Hal ini juga berkaitan dengan pemenuhan kebutuhan agar menghasilkan suatu Sumber Daya Manusia (SDM) yang bermutu dalam hal pekerjaan serta perlu juga mengapresiasikan peningkatan terhadap penegakkan keadilan, pengembangan jati diri yang konkrit terhadap kondisi daripada penyandang difable itu sendiri.

Bagi konsumen GOJEK di dalam melaksanakan perlindungan terhadap pekerja GOJEK penyandang disabilitas tuna rungu itu sendiri mendapatkan respon yang positif di mana dari sisi kualitas layanan, sebanyak lebih dari 90\% pengguna GOJEK khususnya jasa GO-LIFE dan GO-MASSAGE menyatakan puas atas pelayanan yang diberikan oleh mitra penyandang disabilitas tuna rungu sehingga hal ini membuktikan bahwa penyandang disabilitas tuna rungu bukan merupakan hambatan dalam bekerja.

Penyandang disabilitas di dalam masyarakat walaupun mempunyai keterbatasan namun Pemerintah harus tetap memperhatikan agar terciptanya suatu peraturan yang terstruktur

${ }^{18}$ Sulistyo Saputro et. al., op. cit., h. 44. 
dan berkeadilan di dalam implementasi kesetaraan penyandang difable sesuai dengan Undang-Undang Ketenagakerjaan.

Oleh karena itu, kebijakan pemerintah untuk mendayagunakan tenaga kerja penyandang disabilitas tuna rungu masih perlu diadakan adanya perluasan jangkauan agar terjadinya perataan terhadap kerjasama dari segi lembaga Pemerintah maupun milik swasta serta dalam hal untuk mengembangkan suatu potensi, kemampuan serta jati diri yang dimiliki oleh penyandang difable dengan dorongan serta motivasi baik dari lingkungan keluarga, masyarakat maupun pemerintah dalam hal melakukan support maupun mendampingi pengembangan dalam hal kesetaraan hak kerja terhadap penyandang disabilitas itu sendiri.

\section{PENUTUP}

\subsection{Kesimpulan}

1. Terkait dengan pengaturan perlindungan hukum pekerja Perusahaan GOJEK bagi penyandang disabilitas tuna rungu diatur dalam Pasal 5, Pasal 6 dan Pasal 67 UU Nomor 13 Tahun 2003 tentang Ketenagakerjaan di mana Pasal 67 ayat (1) lebih menekankan bagi pengusaha yang mempekerjakan tenaga kerja penyandang disabilitas wajib memberikan perlindungan seperti penyediaan aksesibilitas, pemberian alat kerja, dan alat pelindung diri yang disesuaikan dengan jenis dan kecatatannya.

2. Upaya pemerintah di dalam melaksanakan penegakkan hukum yang berkeadilan dalam hal pekerjaan bagi penyandang disabilitas tuna rungu mengintegrasikan pihakpihak yang terkait untuk memberikan pelatihan dan program pemberdayaan agar penyandang disabilitas di sini menjadi 
tenaga kerja yang profesional dan bermutu sesuai pekerjaan dengan kualifikasi yang diisyaratkan yang diwujudkan dalam bentuk sertifikat bagi tenaga kerja penyandang disabilitas tuna rungu.

\subsection{Saran}

1. Seharusnya perusahaan-perusahaan lainnya tidak menolak penyandang disabilitas dalam memperoleh hak pekerjaan untuk memperoleh persamaan kedudukan dan kesetaraan tanpa diskriminasi bagi penyandang disabilitas tuna rungu.

2. Dalam rangka menjaga profesionalisme dan reputasi penyandang disabilitas sebagai tenaga kerja diharapkan kepada Dinas Tenaga Kerja agar memperbanyak memberikan kesempatan bagi pekerja penyandang disabilitas untuk memperoleh sertifikasi dan mengintensifkan promosi tenaga kerja penyandang disabilitas kepada perusahaanperusahaan.

\section{DAFTAR PUSTAKA}

\section{Buku}

Agusmidah, 2010, Dinamika Hukum Ketenagakerjaan, USU Press, Medan.

Ediwarman, 2015, Monograf Metodologi Penelitian Hukum: Panduan Penulisan Skripsi, Tesis dan Disertasi, PT Sofmedia, Medan.

Marzuki, Peter Mahmud, 2016, Penelitian Hukum Edisi Revisi, Prenadamedia Group, Jakarta.

Rusli, Hardijan, 2011, Hukum Ketenagakerjaan Berdasarkan UU No. 13/2003 tentang Ketenagakerjaan dan Peraturan Terkait Lainnya Edisi Kedua, Ghalia Indonesia, Bogor.

Saputro, Sulistyo et. al., 2015, Analisis Kebijakan Pemberdayaan dan Perlindungan Sosial Penyandang Disabilitas, Deputi Bidang Koordinasi Penanggulangan Kemiskinan dan Perlindungan Sosial, Surakarta.

Soekanto, Soerjono dan Sri Mamudji, 2015, Penelitian Hukum Normatif Suatu Tinjauan Singkat, PT Raja Grafindo Persada, Jakarta. 
Udiana, I Made, 2018, Industrialisasi dan Tanggung Jawab Pengusaha terhadap Tenaga Kerja Terlibat Hukum, Udayana University Press, Denpasar.

Udiana, I Made, 2016, Kedudukan dan Kewenangan Pengadilan Hubungan Industrial, Udayana University Press, Denpasar.

\section{Jurnal}

Hamidi, Jazim, 2016, "Perlindungan Hukum terhadap Disabilitas dalam Memenuhi Hak Mendapatkan Pendidikan dan Pekerjaan", Jurnal Hukum Ius Quia Iustum Faculty of Law Universitas Islam Indonesia, Volume 23 Nomor 4, Oktober 2016.

Hernawati, Tati, 2007, "Pengembangan Kemampuan Berbahasa dan Berbicara Tuna Rungu", Jurnal Jurusan PLB FIP Universitas Pendidikan Indonesia, Volume 7 Nomor 1, Juni 2007.

Kusumastuti, Maria Nurma Septi, 2016, "Perlindungan Hukum dari Diskriminasi bagi Penyandang Disabilitas dalam Dunia Kerja", Jurnal Hukum Program Kekhususan Hukum Ekonomi dan Bisnis Fakultas Hukum Universitas Atma Jaya (UAJY).

Yuni Ratnasari dan Made Suksma Prijandhini Devi Salain, 2016, "Perlindungan Hukum bagi Pekerja Disabilitas terhadap Hak Memperoleh Pekerjaan", Jurnal Hukum Bisnis Fakultas Hukum Universitas Udayana, Vol. 04 No. 03, April 2016.

\section{Tesis}

Kristanti, Alvina, 2013, "Perlindungan Hukum terhadap Tenaga Kerja Penyandang Cacat atas Hak Mendapatkan Pekerjaan Dikaitkan dengan Peraturan Perundang-undangan Ketenagakerjaan", Tesis Fakultas Hukum Universitas Kristen Maranatha, Jawa Barat.

\section{Peraturan Perundang-undangan}

Undang-undang Dasar Negara Republik Indonesia Tahun 1945.

Undang-undang Nomor 39 Tahun 1999 tentang Hak Asasi Manusia (LNRI Tahun 1999 Nomor 165, TLNRI Nomor 3886).

Undang-undang Nomor 13 Tahun 2003 tentang Ketenagakerjaan (LNRI Tahun 2003 Nomor 39, TLNRI Nomor 4279).

Undang-undang Nomor 8 Tahun 2016 tentang Penyandang Disabilitas (LNRI Tahun 2016 Nomor 69, TLNRI Nomor 5870). 